\title{
Interaction of fish oil and a glucocorticoid on metabolic responses to an oral glucose load in healthy human subjects
}

\author{
Jacques Delarue ${ }^{1}$, Chang-Hong $\mathrm{Li}^{2}$, Richard Cohen ${ }^{3}$, Charlotte Corporeau ${ }^{1}$ and Brigitte Simon ${ }^{4}$ \\ ${ }^{1}$ Equipe d'Accueil 948 'Oxylipides', Laboratoire Régional de Nutrition Humaine, Faculté de Médecine de Brest \& CHU, F-29200 \\ Brest, France \\ ${ }^{2} J e u n e$ Equipe 313 'Lipides et Croissance', Faculté de Médecine, F-37000 Tours, France \\ ${ }^{3}$ Fédération de Biochimie, biologie spécialisée, immunoanalyse, Hôpital Edouard Herriot, F-69000 Lyon, France \\ ${ }^{4}$ Equipe d'Accueil 948 'Oxylipides', Faculté de Médecine de Brest, F-29200 Brest, France
}

(Received 7 April 2005 - Revised 11 September 2005 - Accepted 21 September 2005)

\begin{abstract}
Compared with saturated fat, $n$-3 long-chain PUFA-rich fish oil improves insulin sensitivity in rats. We studied whether $n$ - 3 long-chain PUFA could prevent insulin resistance induced by dexamethasone (a glucocorticoid) in healthy human volunteers. A group of eight subjects was studied twice after a $2 \mathrm{~d}$ dexamethasone treatment, before and after a 3-week supplementation with fish oil (providing daily doses of $1 \cdot 1 \mathrm{~g} 20: 5 n-3$ and $0.7 \mathrm{~g} 22: 6 n-3)$. The subjects were studied during the basal state and over the $6 \mathrm{~h}$ following an oral glucose load $(1 \mathrm{~g} / \mathrm{kg})$. Plasma glucose fluxes were traced with $\left[6,6-{ }^{2} \mathrm{H}_{2}\right]$ glucose and $\left[{ }^{13} \mathrm{C}\right]$ glucose (naturally ${ }^{13} \mathrm{C}$-enriched corn glucose). Substrate oxidation was obtained from indirect calorimetry. Following fish oil supplementation, plasma glucose fluxes and substrate oxidation were maintained despite a $17 \%$ reduction $(P<0.05)$ in the area under the curve of plasma insulin response, suggesting an insulin-sensitizing effect.
\end{abstract}

Eicosapentaenoic acid: Docosahexaenoic acid: Polyunsaturated fatty acids: Stable isotopes: Insulin resistance

In rats, fish oil substitution in a high-fat or a high-sucrose diet prevents insulin resistance induced by these diets (Storlien et al. 1987, 1991; Podolin et al. 1998; Taouis et al. 2002). In man, contrasting effects of dietary fish oil supplementation have been reported. In healthy subjects, fish oil supplementation $(6 \mathrm{~g} / \mathrm{d}$ over 3 weeks, providing daily doses of $1.1 \mathrm{~g}$ EPA $(20: 5 n-3)$ and 0.7 g DHA $(22: 6 n-3))$ decreased the insulinaemic response to an oral glucose load by $40 \%$ while plasma glucose response remained unaffected (Delarue et al. 1996). This suggested a sensitizing effect of fish oil on insulin action, since insulin secretion has been shown to be related to insulin sensitivity (Kahn et al. 2003). However, in patients with type 2 diabetes, fish oil does not reverse insulin resistance (Borkman et al. 1989; Puhakainen et al. 1995; Rivellese et al. 1996) and does not improve plasma glucose control (Montori et al. 2000). Taken together, these studies demonstrate that fish oil is able to prevent insulin resistance in rat models of dietary-induced insulin resistance and to improve glucose metabolism in healthy subjects, but for unclear reasons is probably unable to reverse insulin resistance once it is established (review in Delarue et al. 2004).

Short-term dexamethasone treatment $(2 \mathrm{~d})$ induces a reversible well-characterized insulin resistance in healthy subjects. Dexamethasone is a synthetic glucocorticoid used mainly for treatment of chronic inflammatory diseases and for exploration of the hypophyso-adrenal axis. Insulin resistance induced by dexamethasone translates into decreased insulin-mediated plasma glucose utilization during a euglycaemic hyperinsulinaemic clamp (Tappy et al. 1994; Willi et al. 2002) and by a larger increase in plasma insulin and glucose responses to an oral glucose load (Wajngot et al. 1992; Schneiter \& Tappy, 1998; Willi et al. 2002). Dexamethasone decreases phosphatidylinositol 3'-kinase activity (Saad et al. 1993) and the translocation of GLUT4 glucose transporters in rat muscle (Dimitriadis et al. 1997; Weinstein et al. 1998), both abnormalities also present in muscle of patients with type 2 diabetes (Cusi et al. 2000; Ryder et al. 2000). Troglitazone, a pharmacological ligand of PPAR $\gamma$, has been demonstrated to antagonize the metabolic effects of dexamethasone in healthy human subjects. This translates into both a marked reduction of the excessive plasma insulin responses to oral glucose and an increase in plasma glucose utilization during a euglycaemic hyperinsulinaemic clamp (Willi et al. 2002). Because 20:5n-3 is a natural ligand of PPAR and because fish oil prevents the decrease in phosphatidylinositol $3^{\prime}$ kinase and GLUT 4 content in muscle of rats fed a diet high in n-6 PUFA (Taouis et al. 2002), dietary fish oil supplementation could antagonize the metabolic effects of dexamethasone in healthy human subjects.

To verify this hypothesis, the aim of the present work was to determine whether a 3-week dietary fish oil supplementation $(6 \mathrm{~g} / \mathrm{d}$, providing $1.1 \mathrm{~g} 20: 5 n-3$ and $0.7 \mathrm{~g} 22: 6 n-3$ 
daily) was able to prevent, at least in part, the metabolic alterations induced by a $2 \mathrm{~d}$ treatment with dexamethasone in healthy subjects following an oral glucose load $(1 \mathrm{~g} / \mathrm{kg})$.

\section{Subjects and methods}

\section{Subjects}

Eight healthy subjects (six males, two females; mean age $25 \cdot 4$ (SE 0.2) years, mean weight 61.5 (SE 3.2) kg and mean BMI $20 \cdot 7(\mathrm{SE} 1.2) \mathrm{kg} / \mathrm{m}^{2}$ ) were studied. The subjects were in good health, non-smokers and were not taking any drugs. None had a personal or family history of diabetes or hypertension. The subjects did not regularly take part in any strenuous physical activity and had no history of endurance training. Female subjects were studied during the follicular phase of their menstrual cycle. The experimental protocol was approved by the Ethical Committee of Tours. Before participating in the study, each subject gave informed written consent.

\section{Materials}

The fish oil was kindly provided by Roche (Ropufa 30; Roche, Basel, Switzerland). Oral glucose from corn was purchased from Sigma-Aldrich Chimie (Lyon, France). Its isotopic enrichment in ${ }^{13} \mathrm{C}$ was 1.0974 at $\%$. $\left[6,6-{ }^{2} \mathrm{H}_{2}\right]$ Glucose ( $99 \mathrm{~mol} \%$ excess) was purchased from Cambridge Isotopes Laboratory (Andover, MA, USA). Isotopic and chemical purity were checked by GC-MS (Hewlett-Packard 5971 series II instrument; Hewlett-Packard, Les Ulis, France). The $\left[6,6-{ }^{2} \mathrm{H}_{2}\right]$ glucose was prepared as sterile pyrogen-free solutions in normal saline. The solution was filtered through a $0.22 \mu \mathrm{m}$ Millipore filter (Millipore Corp., Bedford, MA, USA) during priming and intravenous infusion.

\section{Study design}

Each subject was studied twice, 3 weeks apart. At day -2 and day -1 of each of the two tests the subjects were given $2 \mathrm{mg}$ dexamethasone per os $(4 \times 0.5 \mathrm{mg} / \mathrm{d})$. Over the 3 weeks between the two tests, the subjects received a dietary supplementation with fish oil given as six capsules of $1 \mathrm{~g}$ each daily (two capsules at breakfast, two capsules at lunch and two capsules at dinner, providing total daily doses of $1.1 \mathrm{~g}$ $20: 5 n-3$ and $0 \cdot 7 \mathrm{~g} 22: 6 n-3$ fatty acids).

All experiments began in the morning after an overnight fast. The diet consumed $2 \mathrm{~d}$ preceding the studies was standardized to provide $200 \mathrm{~g}$ carbohydrates/d. Subjects were asked to maintain their usual physical activity. Ethanol was excluded and coffee intake was restrained to one cup a day throughout the study. On the morning of each experiment, the subjects reported to the laboratory at 07.00 hours. After voiding, they were transferred to a bed where they remained quietly in a semi-recumbent position. An indwelling catheter was inserted in a vein of the right wrist for blood sampling. This vein was kept open by a slow infusion of isotonic saline. The right hand was maintained in a box heated at $56^{\circ} \mathrm{C}$ in order to achieve partial arterialization of venous blood. A second indwelling catheter was inserted in a deep vein of the contralateral arm for tracer infusion. At $t=-150 \mathrm{~min}$, a primed $(5.6 \mathrm{mg} / \mathrm{kg})$ constant $\left(0.07 \mathrm{mg} / \mathrm{kg}\right.$ per min) infusion of $\left[6,6-{ }^{2} \mathrm{H}_{2}\right]$ glucose was started and maintained over $510 \mathrm{~min}$. At $t=0 \mathrm{~min}$, the subjects ingested a solution of naturally ${ }^{13} \mathrm{C}$-enriched glucose, $1 \mathrm{~g} / \mathrm{kg}$, over a $5 \mathrm{~min}$ period. A blood sample was taken at $t=-150 \mathrm{~min}$ for determination of plasma glucose enrichment in ${ }^{2} \mathrm{H}$ and ${ }^{13} \mathrm{C}$ before tracer infusion. Other blood samples were taken at $t=0 \mathrm{~min}$, then every $30 \mathrm{~min}$ until $t=240 \mathrm{~min}$ and then every $60 \mathrm{~min}$ from $t=240$ to $360 \mathrm{~min}$ for determination of isotopic enrichment in ${ }^{2} \mathrm{H}$ and ${ }^{13} \mathrm{C}$ of plasma glucose, and substrate and insulin concentrations. Gas exchange measurements were performed from $t=-60 \mathrm{~min}$ to $t=360 \mathrm{~min}$ using a ventilated canopy, as described previously (Delarue et al. 1994). Urine was collected during experiments for determination of $\mathrm{N}$ excretion.

\section{Sampling and analytical procedures}

Blood samples were immediately spun at $4^{\circ} \mathrm{C}$. The plasma was separated into aliquots and frozen at $-80^{\circ} \mathrm{C}$ until time of assay. Urine samples were frozen at $-80^{\circ} \mathrm{C}$ for later determination of total urinary $\mathrm{N}$. Plasma glucose concentrations were measured by the glucose oxidase method using a Beckman glucose analyser 2 (Beckman Instruments, Fullerton, CA, USA). NEFA concentrations were measured by an enzymatic colorimetric method with the use of a commercial kit (NEFA C; Wako Chemicals, Freiburg, Germany). Lactate concentrations were determined using standard enzymatic methods (Bergmeyer et al. 1977). Plasma insulin (INS-IRMA; Biosource Europe SA, Nivelles, Belgium) and C-peptide (Riagnost; Hoechst Behring, Marburg, Germany) concentrations were measured by RIA. The urinary N concentration was determined using the Kjeldahl method (Hawk, 1977). The isotopic enrichment in ${ }^{2} \mathrm{H}$ of plasma glucose was measured by electron impact ionization on the pentaacetate derivative of glucose and the selective monitoring of ions of $\mathrm{m} / \mathrm{z}, 200$ and 202 by GC-MS (Hewlett-Packard 5971, series II) as previously described (Delarue et al. 1996). The isotopic enrichment in ${ }^{13} \mathrm{C}$ of plasma glucose following ingestion of the naturally ${ }^{13} \mathrm{C}$-enriched glucose was measured on the pentaacetate derivative of glucose using $\mathrm{GC}$-isotope ratio MS as previously described (Delarue et al. 1993).

\section{Computations}

Absolute area under the curve was calculated using basal values of plasma glucose or insulin as baseline. The total rates of appearance ( $\mathrm{RaT})$ and disappearance (RdT) of plasma glucose were calculated in non-steady state using the equation of Steele et al. (1956) as modified by De Bodo et al. (1963). Plasma rate of appearance of exogenous glucose (RaE) was calculated by transposition of the Steele equation as proposed by Proietto et al. (1987) and validated by Tissot et al. (1990). Endogenous glucose production was calculated as RaT minus RaE. Metabolic clearance rate of plasma glucose was calculated as RdT/glycaemia. Total carbohydrate and fat oxidations were calculated from $\mathrm{VCO}_{2}, \mathrm{VO}_{2}$ and urinary $\mathrm{N}$ excretion using the equations of Livesey \& Elia (1988).

\section{Statistical analyses}

All data are expressed as means with their standard errors. Comparison of values between the two periods used 
Table 1. Basal plasma metabolites after $2 \mathrm{~d}$ treatment with dexamethasone, with and without chronic fish oil (FO) supplementation (Mean values and their standard errors)

\begin{tabular}{lcccccc}
\hline & \multicolumn{2}{c}{ Without FO } & & \multicolumn{2}{c}{ With FO } & \\
\cline { 2 - 3 } & Mean & SE & & Mean & SE & $\begin{array}{c}\text { Statistical } \\
\text { significance }\end{array}$ \\
\hline Glucose $(\mathrm{mmo} / \mathrm{l})$ & 5.1 & 0.1 & & 5.1 & 0.2 & NS \\
Insulin $(\mathrm{pmol} / \mathrm{l})$ & 66.0 & 3.6 & & 74.4 & 4.2 & $\mathrm{NS}$ \\
Lactate $(\mathrm{mmol} / \mathrm{l})$ & 1.26 & 0.13 & & 0.93 & 0.07 & $\mathrm{NS}$ \\
NEFA $(\mu \mathrm{mol} / \mathrm{l})$ & 754 & 59 & & 676 & 67 & $\mathrm{NS}$ \\
\hline
\end{tabular}

two-way ANOVA with a post hoc test (paired $t$ test). Statistical calculations were performed in Statview ${ }^{\mathrm{TM}}$ II (Abacus Concepts Inc., Berkeley, CA, USA) running on a Powerbook G4 (Apple, Cuppertino, CA, USA).

\section{Results}

\section{Metabolites and insulin}

Basal plasma metabolites and insulin concentrations are reported in Table 1. There was no effect of fish oil on plasma glucose concentrations (Fig. 1(a)) and area under the curve of glucose (439 (SE 17) v. 440 (SE 11) $\mathrm{pmol} / \mathrm{ml}$ per $6 \mathrm{~h}$, without $v$. with fish oil, respectively). Insulinaemia during oral load was significantly lower with fish oil supplementation than without fish oil supplementation (ANOVA, $P<0.05$; Fig. 1(b)). Area under the curve of insulin was decreased by $17 \%$ with fish oil $v$. without fish oil (15220 (SE 1200) v. 18280 (SE 1210) $\mathrm{pmol} / \mathrm{ml}$ per 6h, respectively; $P<0.05)$. There was no effect of fish oil on plasma C-peptide (Fig. 1(c)), lactate and NEFA concentrations during the oral glucose load (Fig. 2(a and b)).

\section{Plasma glucose fluxes}

Basal RaT glucose was not different with and without fish oil supplementation (2.04 (SE 0.12) v. $2.14(\mathrm{SE} 0.12) \mathrm{mg} / \mathrm{kg}$ per min, respectively). Plasma glucose RaT, RdT and metabolic clearance rate (Fig. 3(a-c)) were not different with and without fish oil supplementation. RaE (Fig. 4(a)) and endogenous glucose production (Fig. 4(b)) were not different without and with fish oil.

\section{Substrate oxidation}

Basal carbohydrate oxidation was not different with and without fish oil supplementation (1.03 (SE 0.16) v. 1.24 (SE 0.1) mg/kg per min, respectively). Basal lipid oxidation was not different with and without fish oil supplementation (1.17 (SE 0.1) v. 1.10 (SE 0.07) $\mathrm{mg} / \mathrm{kg}$ per min, respectively). Carbohydrate and lipid oxidations during oral glucose were not different without and with fish oil supplementation. (Fig. 5( $a$ and $b$ )).

\section{Discussion}

We have assessed the interaction between fish oil and glucocorticoids on the metabolic responses to oral glucose in healthy human subjects. Dexamethasone was chosen because it induces insulin resistance (Wajngot et al. 1992; Tappy et al. 1994; Schneiter \& Tappy, 1998; Willi et al. 2002; Nicod et al. 2003).

Fish oil supplementation induced a modest but significant $17 \%$ decrease in plasma insulin response without altering
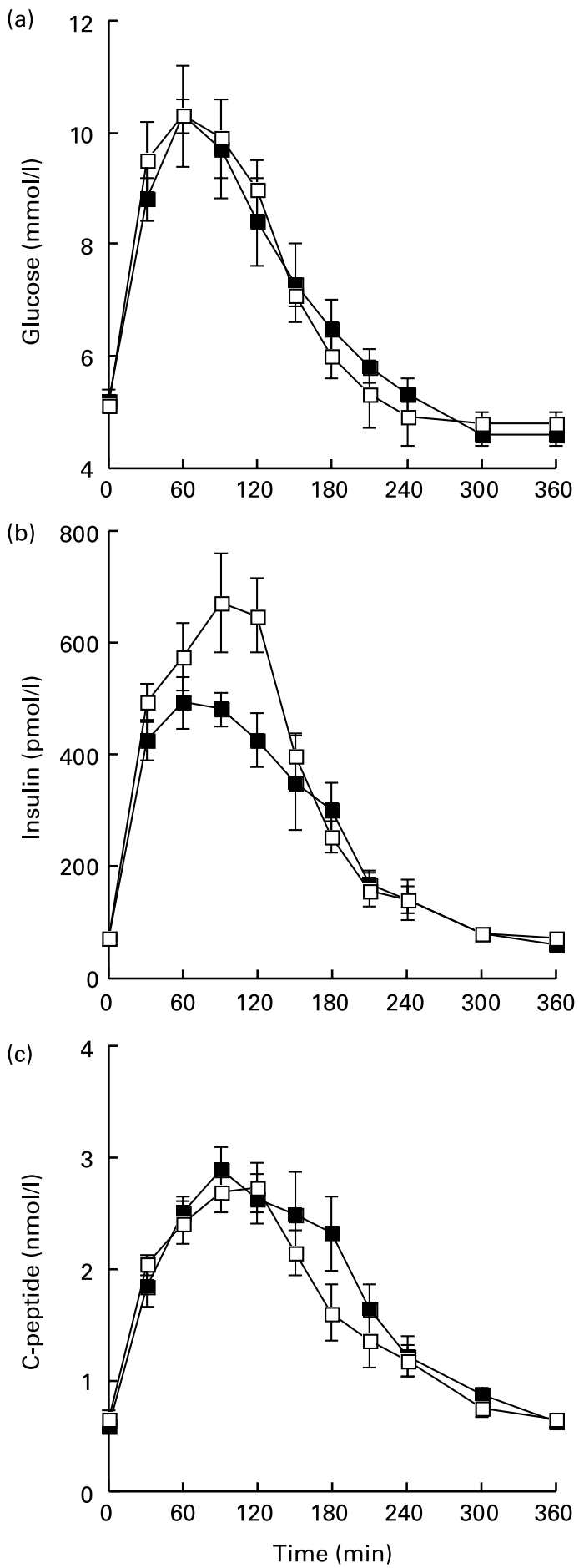

Fig. 1. Time course of plasma glucose (a), insulin (b) and C-peptide (c) in eight healthy subjects, pretreated with dexamethasone, without ( $\square$ ) or with (ם) 3-week fish oil supplementation. Values are means with their standard errors shown by vertical bars. Fish oil supplementation had no statistically significant effect on glucose or C-peptide concentrations, but reduced insulin concentrations significantly compared with non-supplemented values $(P<0.05$, ANOVA $)$. 

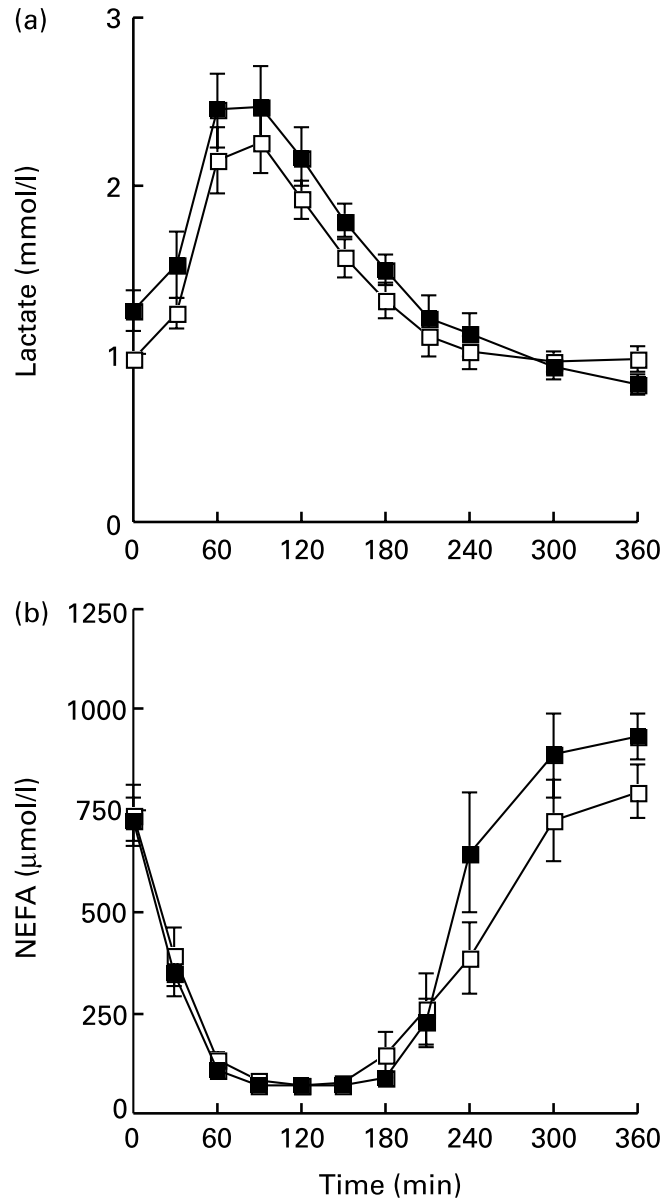

Fig. 2. Time course of plasma lactate (a) and NEFA (b) in eight healthy subjects, pretreated with dexamethasone, without $(\square)$ or with $(\square)$ 3-week fish oil supplementation. Values are means with their standard errors shown by vertical bars. Fish oil supplementation had no statistically significant effect on lactate or NEFA concentrations.

other metabolic parameters. The maintenance of plasma glucose disappearance and of substrate oxidation despite the significant decrease in plasma insulin response suggests an insulin-sensitizing effect of fish oil. The lack of effect of fish oil on plasma $\mathrm{C}$-peptide response and on the molar ratio of plasma C-peptide : insulin argues against an effect on insulin secretion or insulin clearance. We have previously reported a $40 \%$ decrease in plasma insulin response after the same amount of fish oil supplementation in healthy subjects not pretreated with dexamethasone (Delarue et al. 1996). This larger effect of fish oil without dexamethasone can be explained mainly by the potent negative impact of dexamethasone on insulin sensitivity, preventing fish oil from exerting its full positive effect. Willi et al. (2002) have previously reported that the insulin-sensitizer troglitazone totally prevented the deleterious effect of dexamethasone on insulin sensitivity. In comparison, fish oil in the present study decreased postprandial insulin response, suggesting that it indeed prevented some of the metabolic effects of dexamethasone. However, the lowering of insulin concentration was less than with fish oil alone (Delarue et al. 1996), suggesting that fish oil did not completely prevent the effects of dexamethasone. Careful analysis of the data reported by Willi et al. (2002) similarly
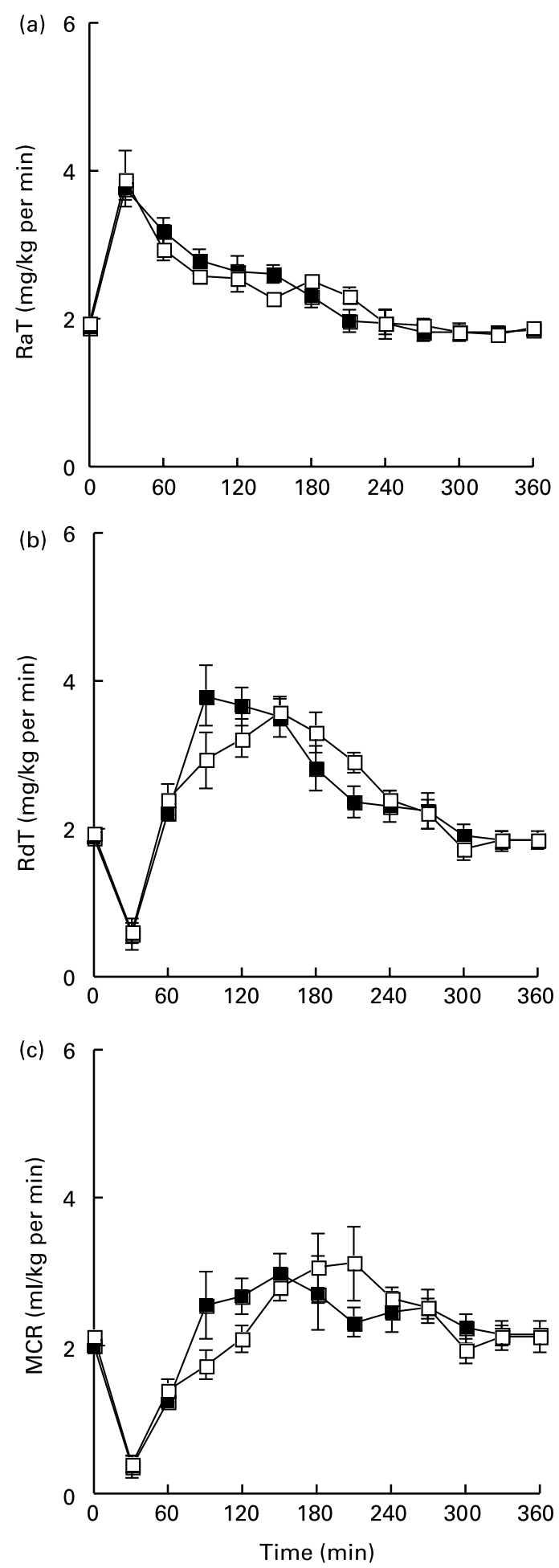

Fig. 3. Time course of plasma glucose total rate of appearance (RaT; a), disappearance $(\mathrm{RdT} ; \mathrm{b})$ and metabolic clearance rate $(\mathrm{MCR} ; \mathrm{c})$ in eight healthy subjects, pretreated with dexamethasone, without $(\square)$ or with (ם) 3-week fish oil supplementation. Values are means with their standard errors shown by vertical bars. Fish oil supplementation had no statistically significant effect on RaT, RdT or MCR.

suggests that troglitazone only partially corrected the effect of dexamethasone, since the postprandial insulin responses remained higher after dexamethasone + troglitazone than after troglitazone alone. 


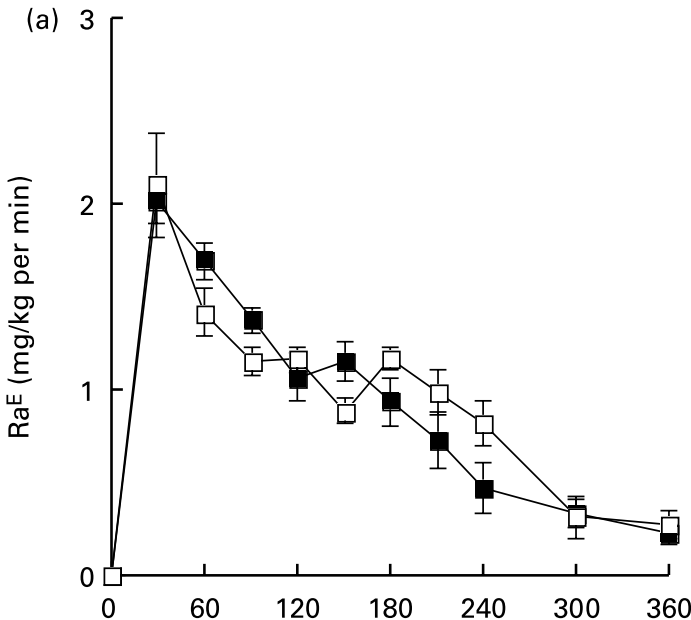

(b)

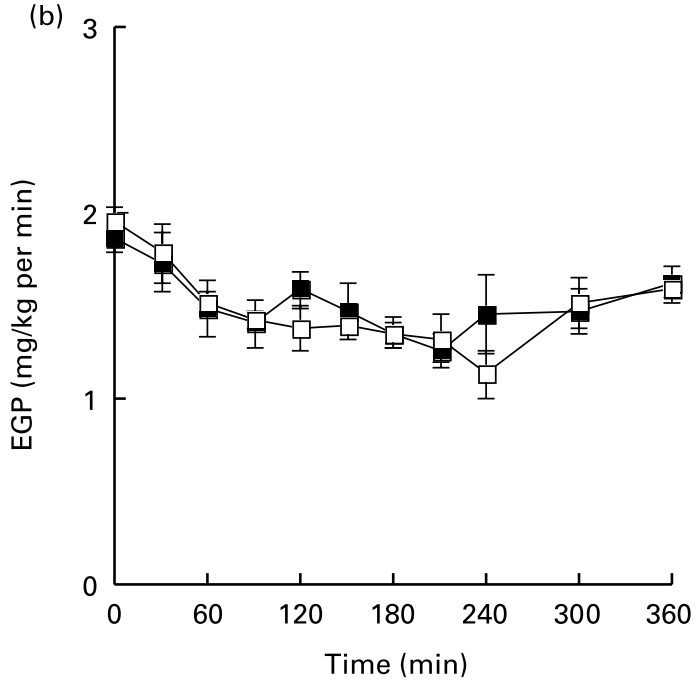

Fig. 4. Time course of rate of exogenous plasma glucose appearance (RaE; a) and endogenous glucose production (EGP; b) in eight healthy subjects, pretreated with dexamethasone, without $(\square)$ or with (ם) 3-week fish oil supplementation. Values are means with their standard errors shown by vertical bars. Fish oil supplementation had no statistically significant effect on RaE or EGP.

The lack of randomization of fish oil intake in our study is an unlikely explanation for its effect on plasma insulin response. A cross-over study would have been an ideal design, but incorporation of $20: 5 n-3$ and $22: 6 n-3$ into membranes has been reported to take as long as 18 weeks (Endres et al. 1989), so that the two experiments should have been performed at least 18 weeks apart. During such a long period other confounding factors could appear. Subjects had very similar basal plasma metabolites and insulin concentrations, as well as basal plasma glucose fluxes and substrate oxidations, on the day of each of the two experiments, which demonstrates a similar metabolic state. Moreover, we have previously checked (data not shown), in a group of healthy subjects, that mean plasma glucose and insulin responses to an oral load of $1 \mathrm{~g}$ glucose $/ \mathrm{kg}$ were similar over a 3-week interval.

In conclusion, the present study shows that a 3-week fish oil supplementation ( $1.8 \mathrm{~g} 20: 5 n-3+22: 6 n-3$ daily) given prior to induction of insulin resistance by a $2 \mathrm{~d}$ dexamethasone treatment did not alter plasma glucose utilization and substrate oxidation despite a significant decrease $(-17 \%)$ in plasma
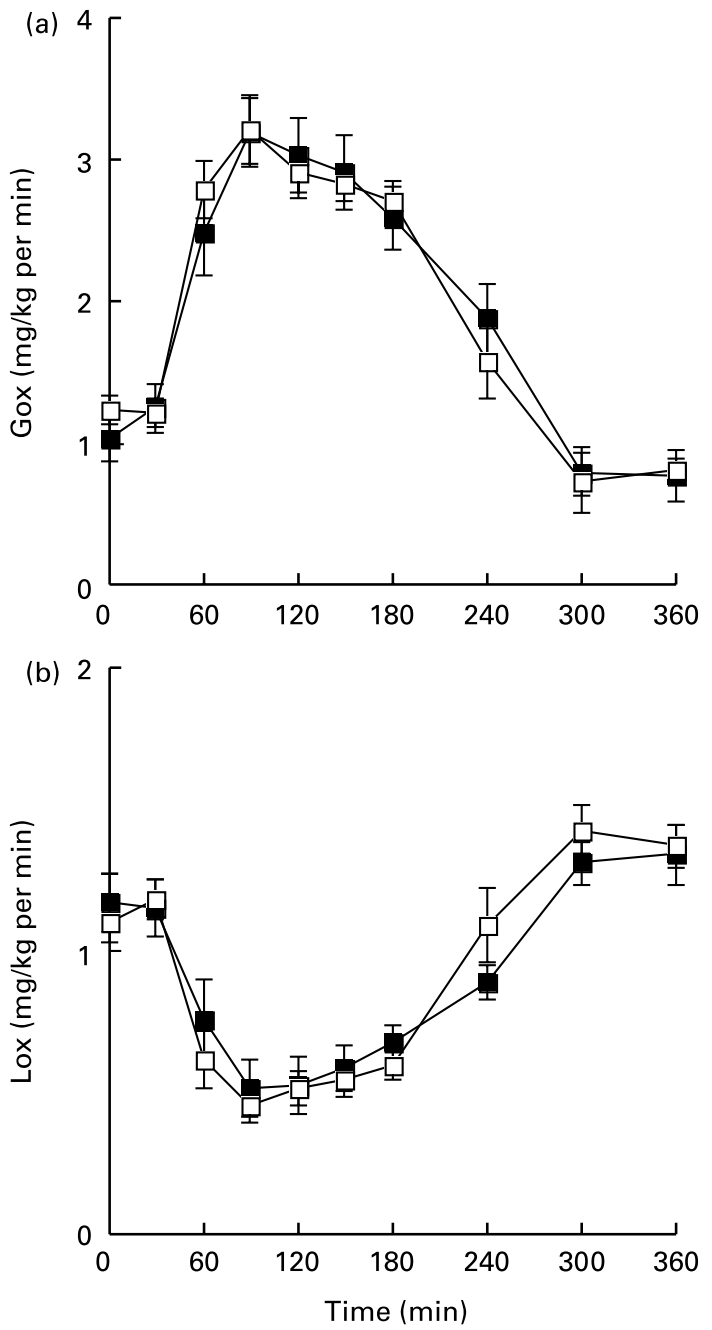

Fig. 5. Whole-body carbohydrate oxidation (Gox; a) and lipid oxidation (Lox; b) in eight healthy subjects, pretreated with dexamethasone, without $(\square)$ or with (ם) 3-week fish oil supplementation. Values are means with their standard errors shown by vertical bars. Fish oil supplementation had no statistically significant effect on Gox or Lox.

insulin response to an oral glucose load. This suggests an insulin-sensitizing effect of fish oil, which could be of potential interest in subjects predisposed to insulin resistance.

\section{Acknowledgements}

This work was supported by a grant from Institut Benjamin Delessert and from both Region Bretagne and Region des Pays de la Loire. Technical help from Mrs Martine Objois is deeply appreciated. We thank Mrs Christiane Pachiaudi from Centre de Recherche en Nutrition Humaine de Lyon for performing the analysis of isotopic enrichment in ${ }^{13} \mathrm{C}$ of plasma glucose.

\section{References}

Bergmeyer HU, Bergmeyer J \& Grassl JM (1977) Methods of Enzymatic Analysis, 3rd ed., vol. VI. Weinheim: Verlag Chemie.

Borkman M, Chisholm DJ, Furler SM, Storlien LH, Kraegen EW, Simons LA \& Chesterman CN (1989) Effects of fish oil 
supplementation on glucose and lipid metabolism in NIDDM. Diabetes 38, 1314-1319.

Cusi K, Maezono K, Osman A, Pendergrass M, Patti ME, Pratipanawatr T, DeFronzo RA, Kahn CR \& Mandarino LJ (2000) Insulin resistance differentially affects the PI 3-kinase- and MAP kinasemediated signaling in human muscle. J Clin Invest 105, 311-320.

De Bodo RC, Steele R, Altszuler N, Dunn A \& Bishop JS (1963) On the hormonal regulation of carbohydrate metabolism: studies with ${ }^{14} \mathrm{C}$ glucose. Recent Prog Horm Res 19, 445-448.

Delarue J, Normand S, Pachiaudi C, Beylot M, Lamisse F \& Riou JP (1993) The contribution of naturally labelled ${ }^{13} \mathrm{C}$ fructose to glucose appearance in humans. Diabetologia 36, 338-345.

Delarue J, Maingourd C, Lamisse F, Garrigue MA, Bagros P \& Couet C (1994) Glucose oxidation after a peritoneal and an oral glucose load in dialyzed patients. Kidney Int 45, 1147-1152.

Delarue J, Couet C, Cohen R, Brechot JF, Antoine JM \& Lamisse F (1996) Effects of fish oil on metabolic responses to oral fructose and glucose loads in healthy humans. Am J Physiol Endocrinol Metab 270, E353-E362.

Delarue J, LeFoll C, Corporeau C \& Lucas D (2004) N-3 long chain polyunsaturated fatty acids: a nutritional tool to prevent insulin resistance associated to type 2 diabetes and obesity?" Reprod Nutr Dev 44, 289-299.

Dimitriadis G, Leighton B, Parry-Billings M, Sasson S, Young M, Krause U, Bevan S, Piva T, Wegener G \& Newsholme EA (1997) Effects of glucocorticoid excess on the sensitivity of glucose transport and metabolism to insulin in rat skeletal muscle. Biochem J 321, 707-712.

Endres S, Ghorbani R, Kelley VE, et al. (1989) The effect of dietary supplementation with $n-3$ polyunsaturated fatty acids on the synthesis of interleukin-1 and tumor necrosis factor by mononuclear cells. N Engl J Med 320, 265-271.

Hawk PB (1977) Kjeldahl method. In Practical Physiological Chemistry, pp. 814-822. Toronto: Blakinston.

Kahn SE (2003) The relative contributions of insulin resistance and beta-cell dysfunction to the pathophysiology of type 2 diabetes. Diabetologia 46, 3-19.

Livesey G \& Elia M (1988) Estimation of energy expenditure, net carbohydrate utilization, and net fat oxidation and synthesis by indirect calorimetry: evaluation of errors with special reference to the detailed composition of fuels. Am J Clin Nutr 47, 608-628.

Montori VM, Farmer A, Wollan PC \& Dinneen SF (2000) Fish oil supplementation in type 2 diabetes: a quantitative systematic review. Diabetes Care 23, 1407-1415.

Nicod N, Giusti V, Besse C \& Tappy L (2003) Metabolic adaptations to dexamethasone-induced insulin resistance in healthy volunteers. Obes Res 11, 625-631.

Podolin DA, Gayles EC, Wei Y, Thresher JS \& Pagliassotti MJ (1998) Menhaden oil prevents but does not reverse sucrose-induced insulin resistance in rats. Am J Physiol Endocrinol Metab 274, R840-R848.

Proietto J, Rohner-Jeanrenaud F, Ionescu E, Terrettaz J, Sauter JF \& Jeanrenaud B (1987) Non-steady-state measurement of glucose turnover in rats by using a one-compartment model. Am J Physiol Endocrinol Metab 252, E77-E84.
Puhakainen I, Ahola I \& Yki-Jarvinen H (1995) Dietary supplementation with $n$-3 fatty acids increases gluconeogenesis from glycerol but not hepatic glucose production in patients with non-insulindependent diabetes mellitus. Am J Clin Nutr 61, 121-126.

Rivellese AA, Maffettone A, Iovine C, Di Marino L, Annuzzi G, Mancini M \& Riccardi G (1996) Long-term effects of fish oil on insulin resistance and plasma lipoproteins in NIDDM patients with hypertriglyceridemia. Diabetes Care 19, 1207-1213.

Ryder JW, Yang J, Galuska D, et al. (2000) Use of a novel impermeable biotinylated photolabeling reagent to assess insulin- and hypoxia-stimulated cell surface GLUT4 content in skeletal muscle from type 2 diabetic patients. Diabetes 49, 647-654.

Saad MJ, Folli F, Kahn JA \& Kahn CR (1993) Modulation of insulin receptor, insulin receptor substrate-1, and phosphatidylinositol 3kinase in liver and muscle of dexamethasone-treated rats. J Clin Invest 92, 2065-2072.

Schneiter P \& Tappy L (1998) Kinetics of dexamethasone-induced alterations of glucose metabolism in healthy humans. Am J Physiol Endocrinol Metab 275, E806-E813.

Steele R, Wall JS, De Bodo RC \& Altszuler N (1956) Measurement of size and turn over rate of body glucose pool by the isotope dilution method. Am J Physiol Endocrinol Metab 187, E15-E24.

Storlien LH, Kraegen EW, Chisholm DJ, Ford GL, Bruce DG \& Pascoe WS (1987) Fish oil prevents insulin resistance induced by high fat feeding in rats. Science 237, 885-888.

Storlien LH, Jenkins AB, Chisholm DJ, Pascoe WS, Khouri S \& Kraegen EW (1991) Influence of dietary fat composition on development of insulin resistance in rats. Diabetes 40, 280-289.

Taouis M, Dagou C, Ster C, Durand G, Pinault M \& Delarue J (2002) $N-3$ polyunsaturated fatty acids prevent the defect of insulin receptor signaling in muscle. Am J Physiol Endocrinol Metab 282, E664-E671.

Tappy L, Randin D, Vollenweider P, Vollenweider L, Paquot N, Scherrer U, Schneiter P, Nicod P \& Jequier E (1994) Mechanisms of dexamethasone-induced insulin resistance in healthy humans. $J$ Clin Endocrinol Metab 79, 1063-1069.

Tissot S, Normand S, Guilluy R, Pachiaudi C, Beylot M, Laville M, Cohen R, Mornex R \& Riou JP (1990) Use of a new gas chromatograph isotope ratio mass spectrometer to trace exogenous ${ }^{13} \mathrm{C}$ labelled glucose at a very low level of enrichment in man. Diabetologia 33, 449-456.

Wajngot A, Giacca A, Grill V, Vranic M \& Efendic S (1992) The diabetogenic effects of glucocorticoids are more pronounced in lowthan in high-insulin responders. Proc Natl Acad Sci U S A 89, 6035-6039.

Weinstein SP, Wilson CM, Pritsker A \& Cushman SW (1998) Dexamethasone inhibits insulin-stimulated recruitment of GLUT4 to the cell surface in rat skeletal muscle. Metabolism 47, 3-6.

Willi SM, Kennedy A, Wallace P, Ganaway E, Rogers NL \& Garvey WT (2002) Troglitazone antagonizes metabolic effects of glucocorticoids in humans: effects on glucose tolerance, insulin sensitivity, suppression of free fatty acids, and leptin. Diabetes 51, 2895-2902. 